Rev. Adam Szot

Archdiocesan Higher Seminary in Bialystok

DOI: 10.15290/rtk.2020.19.14

iD 0000-0001-7778-178X

\title{
The Archbishop of Białystok Romuald Jałbrzykowski and His Curia's Efforts to Release Priests Arrested in the USSR After the Second World War
}

After World War II had ended, the Soviet authorities expelled the Metropoli$\tan$ Archbishop of Vilnius Romuald Jałbrzykowski from Vilnius. He ended up in Białystok, where he established the structures of the local Church known today as the Archdiocese of Białystok. Persecuted and imprisoned by the NKVD, Archbishop Romuald Jałbrzykowski did not forget the priests of the Archdiocese of Vilnius, who were detained, imprisoned, and/or sent to labor camps in the summer of 1945. He made efforts to work with the Polish People's Republic to release those who were being detained. The leaders of the Communist Party in Poland considered the archbishop an enemy of the socialist regime that prevailed in Poland after World War II had ended.

Key words: Archdiocese of Vilnius, Białystok, Archbishop Romuald Jałbrzykowski, Roman Catholic priest, persecution, exile, Soviet Union, Siberia, World War II .

After World War II had ended the Red Army occupied these lands containing the Archdiocese of Vilnius, many priests were arrested by the NKGB (Народный Комиссариат Государственной Безопасности СССР) and imprisoned. The borders determined by the Yalta Conference divided the prewar Archdiocese of Vilnius into three sections. The greatest number of the parishes were located in the Belorussian Soviet Socialist Republic, a considerable number were located in Soviet Lithuania, and the smallest number of parishes were located in the Polish People's Republic. Although Metropolitan of Vilnius Archbishop 
Romuald Jałbrzykowski did not know why these arrests had taken place, he realized that it could have been for national reasons, since the majority of those detained were Polish priests. He was also aware that the territory that the Soviet Union occupied was in open conflict with the Church and had begun the large-scale process of making society atheist.

Archbishop Jałbrzykowski himself had experienced Nazi and Soviet oppression during the Second World War. From March 1942 onward, he was interred in the monastery of the Marians in Mariampol. ${ }^{1}$ After the Red Army invaded the territory in which the Archdiocese of Vilnius was located in 1944, he left Marianpol and returned to Vilnius where religious life was revived and activity at the seminary was resumed. The communist authorities of the Lithuanian Socialist Republic, however, began to persecute the Church. On January 25, 1945, Archbishop Jałbrzykowski was arrested and placed in prison on Ul. Ofiarna. Due to the poor state of his health, however, he was released on February $20,1945 .^{2}$

Based on the reports of the NKVD agents and the Lithuanian Security Police, Archbishop Jałbrzykowski was accused of being in contact with the Polish underground and for directing policies that were hostile to the new authorities of the USSR. In April 1945, the archbishop was of the Church ordered to leave the USSR and go to Poland. ${ }^{3}$

In the middle of July 1945, the Metropolitan of Vilnius was forced to leave Vilnius, and ended up in Białystok. ${ }^{4} \mathrm{He}$ nevertheless continued

$1 \quad$ A. Szot, $A b p$ Romuald Jałbrzykowski metropolita wileński, Lublin 2002; T. Krahel, "Jałbrzykowski, Romuald," Stownik polskich teologów katolickich, vol. 5, Warszawa 1983, 564-570; Idem, "Jałbrzykowski Romuald 1945-1955," in: Archidiecezjalne Wyższe Seminarium Duchowne w Biatymstoku 1945-1980, ed. E. Ozorowski, Białystok 1981, 67-77; P. Nitecki, Biskupi Kościoła w Polsce wlatach 1965-1999. Stownik biograficzny, Warszawa 2002, 164-166; T. Żychiewicz, "Jałbrzykowski Romuald (1876-1955), arcybiskup wileński," in: Polski Słownik Biograficzny, vol. 10, Wrocław - Warszawa - Kraków 1962-1964, col. 400-401.

2 S. Czyżewski, Wspomnienia o Księdzu Doktorze Romualdzie Jałbrzykowskim Arcybiskupie metropolicie Wileńskim spisane w 1959 r., Wrocław 2015.

$3 \quad$ S. Czyżewski, Wspomnienia o Księdzu Doktorze Romualdzie Jałbrzykowskim Arcybiskupie metropolicie Wileńskim spisane w 1959 r., Wrocław 2015; T. Krahel, "Archidiecezja wileńska," in: Życie religijne w Polsce pod okupacja 1939-1945. Metropolie wileńska i lwowska, zakony, ed. Z. Zieliński, Katowice 1992, 11-65; F. Stopniak, "Archidiecezja wileńska podczas II wojny światowej," Studia Teologiczne, nos. 5-6(1987-1988): 323-361.

4 A.Szot, "Arcybiskup Romuald Jałbrzykowski na białostockiej ziemi (1945-1955)," in: Między Wilnem a Biatymstokiem. 50-lecie śmierci Arcybiskupa Romualda Jałbrzykowskiego, eds. J. J. Milewski, T. Kasabuła, Białystok 2007, 75-112. 
to try to maintain contact with the priests who remained outside the borders of the Polish People's Republic. He cared about what would happen to them, particularly those who were imprisoned and deported to somewhere deep in the Soviet Union.

On August 16, 1954, Archbishop Romuald Jałbrzykowski submitted a letter in which he demanded that efforts be made to enable priests to return from behind the Curzon Line. A significant part of the Archdiocese of Vilnius belonged to the Voivodeship of Białystok, so the ordinary bishop of the diocese turned to the voivode, Stefan Dymbowski, with a request. Archbishop Jałbrzykowski presented the voivode with a list of priests who were imprisoned in Vilnius, Mińsk, and Grodno. ${ }^{5}$ The following priests were detained in Vilnius:

1. Fr. Adam Sawicki - a canon capitular of the Vilnius Basilica, chancellor of the Metropolitan Curia, arrested on January 24, 1945.

2. Fr. Antoni Cichoński - canon capitular of Vilnius, custodian of the Vilnius Basilica, professor at Stefan Batory University in Vilnius, arrested on February 7, 1945.

3. Fr. Lucjan Pereświet-Sołtan - pastor of the parish of Kolonia Kolejowa in Vilnius, arrested on January 30, 1945.

4. Fr. Władysław Kisiel - vicar of the Vilnius Cathedral, prefect of secondary schools in Vilnius, arrested on November 30, 1944.

5. Fr. Aleksander Lachowicz - vicar of the formerly Bernardine parish in Vilnius, arrested on January 5, 1945.

6. Fr. Mikołaj Tapper - vicar of the parish in Ejszyszki, arrested in January 1945.

7. Fr. Gedymin Pilecki - pastor of the parish of Porodumino, arrested in February 1945.

8. Fr. Florian Markowski - pastor of St. Anne parish in Vilnius, arrested in July 1945.

The following priests were detained in Mińsk:

1. Fr. Antoni Borysowicz - pastor in Podbrzezie, arrested on July 2, 1944, deported to the Urals (Verkhotuye District of the Severdlovsk Oblast).

2. Fr. Feliks Karpiński - pastor in Borun, arrested in October 1944.

3. Fr. Jan Romejko - pastor in Łuczaj, arrested in November 1944, deported from Mińsk to the East.

A.Szot, "Utworzenie nowych struktur administracji Kościelnejw Białymstoku po zakończeniu II wojny światowej," in: Repatriacje i migracje ludności pogranicza $w$ XX wieku. Stan badań oraz źródła do dziejów pogranicza polsko-litewskobiatoruskiego. Materiaty konferencyjne dedykowane dr. Henrykowi Majeckiemu, eds. M. Kietliński, W. Śleszyński, Białystok 2004, 126-140. 
The following priests were detained in Grodno: ${ }^{6}$

1. Fr. Czesław Sztejn - pastor in Radun, arrested in January 1945.

2. Fr. Wacław Nurkowski - pastor in Zabłocie, arrested in December 1944.

3. Fr. Teodor Ryłło - retired, arrested in December 1944.

4. Fr. Jan Krukowski - prefect of schools, retired, arrested on November 7, 1944.

5. Fr. Albin Jaroszewicz - priest and dean of Grodno, arrested in July 1945.

6. Fr. Wincenty Borsuk - pastor in Kopciówka, arrested in July 1945.

The Metropolitan of Vilnius explained that Polish society painfully felt the imprisonment of the priests listed above and demanded that they be released as soon as possible and permitted to return to their pastoral work. Archbishop Jałbrzykowski asked the voivode to intercede with the relevant state authorities so that these priests could regain their freedom and return to ministry. ${ }^{7}$

Two days later, Fr. Aleksander Chodyko, the vicar general and pastor of Assumption of the Blessed Virgin Mary parish in Białystok, once again wrote a letter in Archbishop Jałbrzykowski's name to the voivode in Białystok and included a supplemental list of the names of of the Church the priests who had been arrested and deported to the East since the original list was sent on August 16, $1945 .{ }^{8}$ He asked that the voivode intervene in the following priests' release and return to Poland:

1. Fr. Tadeusz Sieczka - pastor in Dziembowo, arrested in 1939, imprisoned in Szczuczyn and deported deep into Russia.

$6 \quad$ The following authors have written about the fate of priests from the Archdiocese of Vilnius who were imprisoned and sent to Soviet labor camps: R. Dzwonkowski, Leksykon duchowieństwa polskiego represjonowanego w ZSRS 1939-1988, Lublin 2003; Z. A. J. Peszkowski, S. Z. M. Zdrojewski, Katoliccy duchowni w Golgocie Wschodu. Odksiędza Pomirskiego do Fr. Niedzielaka, Pelpin-Warszawa-Łódź - Orchard Lake 2002; T. Krahel, Martyrologia duchowieństwa archidiecezji wileńskiej 1939-1945, Białystok 2017; Idem, Martyrologia duchowieństwa archidiecezji wileńskiej 1939-1945, $2^{\text {nd }}$ ed., Białystok 2017; Idem, Przez więzienia iobozy do kapłaństwa. Wojenne losy alumnów Seminarium Duchownego w Wilnie, Białystok 2015.

7 L. Mikhailik (Michajlik), Kościół katolicki na Grodzieńszczyźnie 1939-1945, Warszawa 2008.

8 Archiwum Archidiecezjalne w Białymstoku[Archdiocese of Białystok Archives] (abbreviated hereafter as: AAB), Pismo abpa R. Jałbrzykowskiego do wojewody białostockiego [Archbishop R. Jałbrzykowski's letters to the voivode of Białystok], August 16, 1945, no. 19/45, Korespondencja z urzędami państwowymi 1945-1956 [Correspondence with State Official 1945-1956]. 
2. Fr. Tomasz Żebrowski - pastor in Wiszniewo, arrested and deported in 1939.

3. Fr. Edward Zdanowicz - pastor in Jelnia, arrested and deported in 1940.

4. Fr. Jan Goj - pastor in Rohotna, arrested and deported in 1940.

5. Fr. Paweł Sargiewicz - pastor in Tryczówka, arrested and deported in 1940.

6. Fr. Mikołaj Wagner - pastor in Narewka, arrested and deported in 1940.

7. Fr. Władysław Grzegorski - pastor in Łopienica, arrested and deported in 1940.

8. Fr. Stanisław Matyszczyk - vicar in Widzów, arrested and deported in 1940.

9. Fr. Michał Szymankiewicz - vicar from Opsa, arrested and deported in 1941.

10. Fr. Bolesław Zabłudowski - pastor in Pelikany, arrested and deported in 1941.

11. Fr. Antoni Mańturzyk - prefect of schools in Podbrodzie, deported from the prison in Lithuania as a Polish Army chaplain.

12. Fr. Nikodem Dubrowka - prefect of schools and pastor in Bakszty, deported from Lithuania as a Polish Army chaplain.

13. Fr. Czesław Kulikowski - pastor Bobrowszczyźna, deported from a camp in Lithuania as a Polish Army chaplain.

14. Fr. Franciszek Tyczkowski -Polish Army chaplain, deported deep into Russia.

15. Fr. Jan Żuk - pastor from Plyussy, arrested and deported in 1939.

Archbishop Jałbrzykowski's letter from August 1945 was sent from the Ministry of Foreign Affairs in Warsaw to the Embassy of the Polish People's Republic in Moscow. ${ }^{9}$

The Metropolitan Curia of Vilnius, which was located in Białystok, did not stop only at writing letters. In October 1945, documents regarding the repatriation of priests from the territory of the USSR were issued. These letters pertained to many priests from the Archdiocese of Vilnius, the majority of whose names were provided in August 1945. Brief notes about every priest were included: biographical information, the locations of their last pastoral assignments, often the date of their arrest, and the places to which they were exiled. On October 23, 1945, the Metropolitan renewed his request to the Chief Agent for matters

AAB, Pismo Fr. Aleksandra Chodyki, wikariusza generalnego do wojewody białostockiego [The Letters of Vicar General Fr. Alexander Chodyko to the voivode of Białystok], August 18, 1945, nr 20/45, Korespondencja z urzędami państwowymi 1945-1956 [Correspondence with State Official 1945-1956]. 
concerning the repatriation of Poles from the USSR. He had received a notification that his application had been registered. He wished to hasten the return of his priests, however, and believed that they were being punished only because they, by being Poles, had brought upon themselves the Lithuanian or Belarusian Soviets' hatred. He attached the following list of 35 priests who had been arrested and deported to his letter to Minister Zygmunt Modzelewski: ${ }^{10}$

1. Fr. Adam Sawicki - chancellor of the Metropolitan Curia of Vilnius, canon capitular of Vilnius, arrested on January 24, 1945, deported to Vorkuta,

2. Fr. Antoni Cichoński - professor of Stefan Batory Univeristy, canon capitular of Vilnius, arrested on February 7, 1945 in Vilnius, sent to Vorkuta,

3. Fr. Aleksander Lachowicz - arrested on January 5, 1945 in Vilnius, exiled to southern Kazakhstan.

4. Fr. Władysław Kisiel - vicar of the Cathedral in Vilnius, arrested on October 30, 1944, deported to southern Kazakhstan.

5. Fr. Józef Prejser - arrested in 1944, deported to Kaluga, suspected of belonging to the Home Army.

6. Fr. Gedymin Pilecki - arrested in February 1945, deported to southern Kazakhstan.

7. Fr. Lucjan Pereświet-Sołtan - pastor in Kolonia Kolejowa in Vilnius, arrested on January 30, 1945, exiled to Vorkuta.

8. Fr. Wacław Nurkowski - pastor in Zabłocie, arrested in December 1944.

9. Fr. Teodor Ryłło - retired, arrested and imprisoned in Grodno on December 7, 1944.

10. Fr. Jan Krukowski - retired, arrested and imprisoned in Grodno on December 7, 1944

11. Fr. Albin Jaroszewicz - dean and pastor in Grodno, arrested and imprisoned in Grodno in July 1944.

12. Fr. Michał Szymankowicz - vicar in Opsa, arrested and taken deep into Russia in 1941.

13. Fr. Stanisław Matyszczyk - vicar in Widzów, arrested and taken deep into Russia in 1940.

14. Fr. Władysław Grzegorski - pastor in Łopienica, arrested and taken deep into Russia in 1940.

15. Fr. Mikołaj Wagner - pastor in Narewka, arrested in 1940.

10 AAB, Zawiadomienie z MSZ [Notification from the Ministry of Foreign Affairs], October 22, 1945, no. 3849/45, Korespondencja z urzędami państwowymi 19451956 [Correspondence with State Official 1945-1956]. 
16. Fr. Paweł Sargiewicz - pastor in Tryczówka, arrested in 1940.

17. Fr. Jan Goj - pastor in Rohotna, arrested and taken deep into Russia in 1940.

18. Fr. Edward Zdanowicz - pastor in Jelnia, arrested in 1940.

19. Fr. Tomasz Żebrowski - pastor in Wiszniewo, arrested and taken deep into Russia in 1939.

20. Fr. Tadeusz Sieczka - pastor in Dziembrów, arrested and taken deep into Russia in 1939.

21. Fr. Piotr Rogiński - pastor in Rzeszów, arrested and taken deep into Russia in 1940.

22. Fr. Nikodem Dubrowka - prefect of schools and pastor in Bakszty, deported as a Polish Army chaplain to a camp in Lithuania in 1941.

23. Fr. Czesław Kulikowski - pastor in Bobrowszczyźna, deported as a Polish Army chaplain to a camp in Lithuania in 1941.

24. Fr. Jan Żuk - pastor in Plyussy, arrested and taken deep into Russia in 1939.

25. Fr. Stefan Kiwiński - pastor in Narwiliszki, arrested and taken deep into Russia in 1941.

26. Fr. Michał Sucharewicz - pastor in Spas, arrested and taken deep into Russia in 1945.

27. Fr. Bolesław Zabłudowski - pastor in Pelikany, arrested and taken deep into Russia in 1941.

28. Fr. Jan Romejko - pastor in Łuczaj, arrested and taken deep into Russia in 1944.

29. Fr. Mikołaj Tapper - vicar in Ejszyszki, arrested in January 1945.

30. Fr. Wincenty Borsuk - pastor in Kopciówka, arrested in July 1945 and imprisoned in Grodno.

31. Fr. Antoni Borysowicz - arrested on December 24, 1944 and exiled to the Urals.

32. Fr. Feliks Karpiński - pastor in Boruny, arrested in October 1944 and imprisoned in Mińsk.

33. Fr. Florian Markowski - pastor of St. Anne parish in Vilnius, arrested in July 1945.

34. Fr. Czesław Sztejn - pastor in Radun, arrested in July 1945, imprisoned in Grodno.

35. Fr. Antoni Mańturzyk - prefect of schools in Podbrodzie, Polish Army chaplain, deported from a camp in Lithuania to Russia.

The Chancellor of the Curia sent a separate request for each of the priest mentioned above to the main government agent for the repatriation of Poles from the USSR, asking that the Soviet authorities release 
the priests and allow them to return to their country where they were being awaited as zealous pastors. ${ }^{11}$ In some instances, the Chancellor argued that they were essential in Białystok as seminary professors, ecclesiastical tribunal officials, or synodal judges. ${ }^{12}$ When writing about Fr. Władysław Kisiel, who was the vicar of the Cathedral church in Vilnius, the prefect for secondary schools in Vilnius, and arrested by the NKGB on November 30, 1944 in Vilnius, the chancellor argued that Fr. Kisiel was needed in Poland as the full-time prefect of secondary schools. In the place of the Curia's Chancellor, Fr. Czyżewski asked the chief agent for the repatriation of the Polish people for the Soviet authorities' permission to release him and the remaining priests.

In the years following 1944, families of priests who remained behind the Curzon Line after World War II sent letters to Archbishop Jałbrzykowski and the Curia of the Archdiocese of Białystok, asking for assistance in bringing their relatives back to Poland. Many of the letters concerned religious who were detained by the NKGB after World War II and exiled to Russia.

In March 1946, Ludwik Sztejn, the brother of Fr. Czesław Sztejn, who was a pastor in Radunie and imprisoned in January 1945 by the NKGB, asked to be notified if his brother returned to Poland. For several months he tried to secure his brother's return to Poland. In of the Church July and October of 1945, he sent letters to the Headquarters of the chief governmental agent for the Polish People's Republic in Warsaw regarding the necessary efforts to secure Fr. Czesław Sztejn's return to Poland. He had hoped that his request would be taken into consideration, because he had received a notification from the Ministry of Foreign Affairs that the matter regarding his brother's return was referred to the Embassy of the Polish People's Republic in Moscow.

In August 1946, Fr. Aleksander Lachowicz's sister, Bronisława Romanowska, asked the Metropolitan of Vilnius for help in securing her brother's return to Poland. Fr. Lachowicz had served as the vicar in the formerly Bernardine church in Vilnius and was arrested on January 6,1945 . After a long stay in a prison in Vilnius, he was deported to

11 AAB, Pismo abpa R. Jałbrzykowskiego do ministra Z. Modzelewskiego Archbishop R. Jałbrzykowski's letters to the Minister Z Modzelewski], July 28, 1945, no. 402/45, Korespondencjazurzędami państwowymi 1945-1956 [Correspondence with State Official 1945-1956].

12 AAB, Pismo kanclerza Kurii do Ministerstwa Administracji Publicznej w Warszawie [The chancellor of the Curia's letters to the Ministry of Public Administration in Warsaw], October 2, 1945, no.239/45, Korespondencjazurzędami państwowymi 1945-1956 [Correspondence with State Official 1945-1956]. 
Kazakhstan on September 14, 1945. As of August 1946, he was still in the Karaganda Region.

In June 1947, Fr. Józef Bielawski's brother, Dr. Oskar Bielawski, who was the director of the sanatorium for those suffering from nervous disorders in Kościan in the Poznań Voivodeship, asked Archbishop Jałbrzykowski to use all of his status to rescue and repatriate those who had been imprisoned. Fr. Józef Bielawski and his brother Edwin were sentenced to death by order of the court on April 4, 1947. The sentence was changed to 25 years of hard labor. The prisoners' poor health made it impossible for them to be deported to Siberia, so they had to serve their time in a prison in Vilnius. A note written in the margins of the letter states: "settled on June 9, [19]47" and suggests that the letter did not remain unanswered. Certainly, the author of the letter received a response to his letter, but the Archbishop might have sent additional relevant letters to the individual state offices.

From 1946-1948, the Archdiocesan Curia in Białystok issued certificates certifying that the priests mentioned by name had lived in the Republic of Poland before the outbreak of World War II and were, therefore, Polish citizens and still considered themselves as such, despite the changing political conditions. Such certificates were issued to many priests, including, for example, Fr. Fr. Gedymin Pilecki, Fr. Adam Sawicki, Fr. Jan Żuk, Fr. Wacław Nurkowski, to submit to the History relevant state authorities. Usually, these were state agents who dealt with the repatriation of the Polish people from the Lithuanian and Belarusian Socialist Soviet Republics.

Relatives of priests who either remained in the East or were arrested and detained in Soviet labor camps and prisons sent letters to the Curia in Białystok, which often fell into the hands of Archbishop Jałbrzykowski. They counted on Church leaders to help them free the priests or secure their return to Poland. Some of the letters were very personal and dramatic.

Fr. Feliks Karpiński's mother, Bronisława Karpińska from Śmigiel in the Poznań Voivodeship, wrote a letter concerning her son on July 4, 1946. Fr. Karpiński had been arrested by the NKGB on November 11, 1944 in Boruny. He likely was imprisoned in Mińsk until July 10, 1945 and then taken to Moscow. During the Nazi occupation, Bronisława Karpińska was deported to Germany where she performed forced labor. Having returned to Poland, she found out about her son's arrest and deportation. This information was all the more painful because she had already lost one son who died in the concentration camp in Hamburg-Neuengamme. She was elderly, had no close relatives or 
friends, and her health had become impaired after being transported to different German labor camps. Her son, Fr. Feliks, was her entire hope for the remaining years of her life. Based on Poland and the USSR's agreement concerning the repatriation of Poles from Soviet Russia, she was worried that her son would never return to his fatherland.

Responding to a letter from Jani Tapper, the mother of Fr. Mikołaj Tapper, on March 15, 1947, the Chancellor of the Curia of the Archdiocese of Białystok clearly stated that the Metropolitan Archbishop and the Curia took action regarding the case of her son and priest who had been arrested and deported to Russia. These interventions, however, did not effect any positive outcomes. The chancellor suggested that he should make a private request for the release of Fr. Mikołaj Tapper once again. On March 31, 1947, Fr. Mikołaj Tapper's mother wrote a letter to the chancellor, asking that he not forget about her son in his efforts to repatriate priests. Fr. Tapper was arrested in the rectory in Ejszyszki on December 17, 1944. He was transported from the prison in Eukiszki in Vilnius in the middle of August 1945. His mother did not know to where he was deported. She hoped, however, that Polish citizens who had been tried and deported to gulags and forced labor would return to their fatherland as a result of the talks that had taken place between the representatives of both countries. She did not lose of the Church hope that she would one day see her son again.

The extent of the effects of the Metropolitan of Vilnius Archbishop Romuald Jałbrzykowski's efforts to release priests remains unknown. Some of the priests were released, others managed to leave Soviet Russia and return to Poland, and still others remained in the eastern parishes of the Archdiocese of Vilnius and experienced the Soviet regime's hostility for many years..$^{13}$

The Metropolitan of Vilnius and his Curia's efforts to obtain the release of priests from Soviet prisons and labor camps was possible only during the first months and years after the end of World War II. As time passed and the Soviet regime's power strengthened in Poland, Archbishop Jałbrzykowski was perceived as the main enemy of the system and hostile to the changes that had taken place after the war. From the 1940-50s, he was censored and watched closely by the agents of the Security Office. Actions were taken against him in order to remove him from Białystok or intimidate him in other ways. Yet, 
until his death in 1955, the Archbishop remained a steadfast priest and shepherd. ${ }^{14}$

Each priest's life and fate are a separate story that is woven into the image of the "priest of the borderland." All research and even small contributions to uncover the fate of those who remained faithful to God, the Church, and their Fatherland for years for the good of the faithful and the local Church continue to be important.

\section{Bibliography:}

1. Archiwum Archidiecezjalne w Białymstoku [Archdiocese of Bialystok Archives]. Korespondencja z urzędami państwowymi 1945-1956 [Correspondence with State Officals 1945-1956].

2. Czyżewski, S. Wspomnienia o Księdzu Doktorze Romualdzie Jałbrzykowskim Arcybiskupie metropolicie Wileńskim spisane w 1959 r. Wrocław 2015.

3. Dzwonkowski, R. Leksykon duchowieństwa polskiego represjonowanego $w$ ZSRS 1939-1988. Lublin 2003.

4. Krahel, T. "Jałbrzykowski Romuald," Stownik polskich teologów katolickich. Volume 5. Warszawa 1983, 564-570.

5. Krahel, T. "Jałbrzykowski Romuald 1945-1955." In: Archidiecezjalne Wyższe Seminarium Duchowne w Biatymstoku 1945-1980. Edited by E. Ozorowski. Białystok 1981, 67-77.

6. Krahel, T. "Archidiecezja wileńska. In: Życie religijne $w$ Polsce pod okupacja 1939-1945. Metropolie wileńska i lwowska, zakony. Edited by Z. Zieliński. Katowice 1992, 11-65.

7. Krahel, T. Martyrologia duchowieństwa archidiecezji wileńskiej 1939-1945. Białystok 2017.

8. Krahel, T. Martyrologia duchowieństwa archidiecezji wileńskiej 1939-1945. Second Edition. Białystok 2017.

9. Krahel, T. Przez więzienia i obozy do kaptaństwa. Wojenne losy alumnów Seminarium Duchownego w Wilnie. Białystok 2015.

10. Mikhailik, L. Kościót katolicki na Grodzieńszczyźnie 1939-1945. Warszawa 2008.

11. Nitecki, P. Biskupi Kościoła $w$ Polsce w latach 1965-1999. Stownik biograficzny. Warszawa 2002.

14 J. Stefaniak, "Duchowieństwo katolickie wobec władz państwowych w woj. białostockim w latach 1945-1956," Studia Podlaskie, 10(2000): 152-165; K. Sychowicz, "Polityka władz wobec duchowieństwa archidiecezji wileńskiej z siedzibą w Białymstoku w latach 1945-1949," in: Studia i materiaty do dziejów najnowszych ziem pótnocno-wschodnich Polski (1939-1989), ed. J. J. Milewski, Białystok 2004, 113; S. Ożlański, "Stosunki państwo - Kościół w latach 1944-1950 w świetle materiałów źródłowych przechowywanych w zasobie Archiwum Państwowego w Białymstoku," in: 50 lat Archiwum Państwowego w Białymstoku. Księga pamiątkowa, Białystok 2003, 134-146; A. Szot, "Rok 1950 - czas porozumienia, czy przełomu? Z dziejów Kościoła na Białostocczyźnie,” Studia Teologiczne, 28(2010): 411-434. 
History of the Church

12. Ożlański, S. "Stosunki państwo - Kościół w latach 1944-1950 w świetle materiałów źródłowych przechowywanych w zasobie Archiwum Państwowego w Białymstoku." In: 50 lat Archiwum Państwowego $w$ Biatymstoku. Księga pamiątkowa. Białystok 2003, 134-146.

13. Peszkowski, Z. A. J., Zdrojewski, S. Z. M. Katoliccy duchowni w Golgocie Wschodu. Od księdza Pomirskiego do Fr. Niedzielaka. Pelpin - Warszawa - Łódź - Orchard Lake 2002.

14. Stefaniak, J. "Duchowieństwo katolickie wobec władz państwowych w woj. białostockim w latach 1945-1956," Studia Podlaskie 10(2000): 152-165.

15. Stopniak, F. “Archidiecezja wileńska podczas II wojny światowej.” Studia Teologiczne, nos. 5-6(1987-1988): 323-361.

16. Sychowicz, K. "Polityka władz wobec duchowieństwa archidiecezji wileńskiej z siedzibą w Białymstoku w latach 1945-1949." In: Studia i materiaty do dziejów najnowszych ziem pótnocno-wschodnich Polski (19391989). Edited by J. J. Milewski. Białystok 2004, 183-196.

17. Sychowicz, K. "Przeciwnicy władzy ludowej. O abp. Romualdzie Jałbrzykowskim i bp. Stanisławie Kostce Łukomskim." Biuletyn IPN, no. 12(2005): 60-69.

18. Sychowicz, K. "Władza i aparat bezpieczeństwa wobec arcybiskupa Romualda Jałbrzykowskiego (1945-1955)." In: Między Wilnem a Białymstokiem. 50-lecie śmierci Arcybiskupa Romualda Jałbrzykowskiego. Edited by J. J. Milewski, T. Kasabuła. Białystok 2007, 113-128.

19. Szot, A. Abp Romuald Jałbrzykowski metropolita wileński. Lublin 2002.

20. Szot, A. "Arcybiskup Romuald Jałbrzykowski na białostockiej ziemi (1945-1955)." In: Między Wilnem a Biatymstokiem. 50-lecie śmierci Arcybiskupa Romualda Jałbrzykowskiego. Edited by J. J. Milewski, T. Kasabuła. Białystok 2007, 75-112.

21. Szot, A. "Rok 1950 - czas porozumienia, czy przełomu? Z dziejów Kościoła na Białostocczyźnie." Studia Teologiczne 28(2010): 411-434.

22. Szot, A. "Utworzenie nowych struktur administracji Kościelnej w Białymstoku po zakończeniu II wojny światowej." In: Repatriacje i migracje ludności pogranicza $w$ XX wieku. Stan badań oraz źródta do dziejów pogranicza polsko-litewsko-biatoruskiego. Materiaty konferencyjne dedykowane dr Henrykowi Majeckiemu. Edited by M. Kietliński, W. Śleszyński. Białystok 2004, 126-140.

23. Żychiewicz, T. "Jałbrzykowski Romuald (1876-1955), arcybiskup wileński." In: Polski Stownik Biograficzny. Volume 10. Wrocław - Warszawa - Kraków 1962-1964, columns 400-401. 